\title{
The Environmental Problems of Azerbaijan and the Search for Solutions
}

\author{
GADIR BAYRAMLI \\ Department of Economics and Business Administration \\ Faculty of Economics of Turkish World \\ Azerbaijan State University of Economics (UNEC), Baku
}

AZERBAIJAN

Abstract: Environmental issues are one of the current challenges for Azerbaijan. Industrial pollution emerging since the 1870s with the expansion of oil exploration operation in Baku and surrounding areas reached larger scale in some places during the following periods. During the Soviet period oil operations in the Caspian Sea increased when the scope of the problem widened, and the pollution reached an even larger scale during oil extraction and transportation. Oil refineries are located in densely populated areas of Baku and this is one of the main factors causing expansion of the scale of pollution. Oil pollution covers thousands of hectares of lands just in the Absheron Peninsula itself.

Along with the industrial pollution, the pollution in agricultural areas in Azerbaijan has also emerged mainly in the Soviet period. The excessive amount of fertilizer and pesticides used in cotton fields and lack of proper irrigation are considered to be among the main factors of environmental pollution. The impact of environmental damages caused by the Gabala Radar Station built in the Soviet times is still being felt now. Effective environmental policy, providing the enterprises with purifiers, contributions of non-governmental organizations, promotion of environmental awareness and use of the best practice of developed countries can contribute to the solution of the environmental problems.

The most serious environmental problems of Azerbaijan are connected with the occupation of the Azerbaijani territories by Armenia. Armenia has destroyed the forest resources in the occupied territories. Moreover, Basitchay National Reserve, which is located in the occupied Zangilan region and is unique in the world, has been destroyed, and other natural sites have been damaged in the region. Large amount of metal waste thrown from the Armenian metallurgical plants into Okhchuchay River has made its way to Araz River and become a source of serious pollution. Toxic substances thrown into Tartar River are another source of concern. In order to solve the environmental problems in Azerbaijan, it is necessary to carry out an effective state policy, undertake new scientific researches, study best practices of advanced countries, and establish new and up-to-date environmental standards.

Keywords: Azerbaijan, environmental problems, environmental pollution, environmental policy.

Received: November 11, 2019. Revised: May 19, 2020. Accepted: May 29, 2020. Published: June 5, 2020.

\section{Introduction}

The emergence of environmental problems in Azerbaijan started with the development of the oil industry in and around Baku. Later it encompassed other offshore areas, as well as the Caspian Sea. While the cause of the pollution before 1920 was oil, the sources of pollution increased during the Soviet period (1920-1991) and the dimension and the scope of pollution has expanded with the development of other branches of industry and the agricultural sector. Today, Azerbaijan's environmental pollution contains all the elements of nature (air, water and soil). However, there are differences among the regions in terms of scope and impacts of the environmental pollution.

Industrial, agricultural and transportation sectors are in first place among the sources of the environmental pollution in Azerbaijan. The share of the oil industry in the environmental pollution in the country is greater. The pollution during the extraction, transportation and processing of oil have a negative impact over the natural features of the land, air and water, and it has reached to the extent that would be dangerous for human health. The pollution caused by the growing chemical industry linked to the oil industry shows its effects particularly on the Absheron Peninsula. 
Starting from the 1950s, the rapidly developing metallurgical industry caused environmental pollution in the country's western and northern areas, and led to the destruction of forests in some places. Implications of the increasing number of transportation vehicles during the last 15 years have been reflected in the environmental situation and are among the major sources of air pollution in the capital Baku in particular.

The radar station built in the Gabala region in the $1970 \mathrm{~s}$ constitutes the major source of radioactive pollution and its effects are still felt despite the closure of the station, voiced by experts as well. Among the environmental problems of Azerbaijan, the dimension of damages to the nature caused by the Armenian occupation is larger and today its effects are growing. The aforementioned environmental problems of Azerbaijan have been discussed and the air, water and ground pollution of the country have been examined in detail in this article.

Researches carried out in recent years were reviewed for analyzing the current situation concerning the environmental problems in Azerbaijan, and relevant recommendations were suggested for the solution of these problems.

\section{Literature Review}

The environmental problems of soil and forests in Azerbaijan was investigated by H.Aliyev (Alarm Drum, Baku, 2002), the effects of anthropogenic factors on the ecological situation was studied by G. Mammadov and M. Khalilov (Ecology and Protection of the Environment, Baku, "Elm" Press, 2005), soil erosion in Azerbaijan by B. Aliyev and I. Aliyev (Erosion Problems in Azerbaijan and the Ways of Their Solution, Baku, 2002), the impacts of economy on the nature and the problems related to efficient utilization of nature by Shovgi Goeychayli and Telman Ismayilov (Economic and Environmental Bases of Nature Use, Baku, 2009), salinization of lands and melioration measures $\mathrm{E}$. Mammadova (Melioration Hydro-geology, Baku, 2016), soil pollution and the most vital characteristics of soil degradation, as well as problems related to the environmental control over the condition of soil A. Babayev (Monitoring of the Soil Quality and Environmental Control, Baku, 2011), analysis of the use and current changes in quality and quantity indicators of surface and ground water reserves by $\mathrm{F}$. Imanov ve A. Alakbarov (Contemporary Modifications and Integrated Management of the Water Resources of Azerbaijan, Baku, 2017), problems of ecology and revitalization of rivers by $F$. A. Imanov, $R$. A. İsmayllov, A. A. Nuriyev (Revitalization and Ecological Flow of Rivers, Baku, 2019), the environmental situation in the Caspian Sea by Huseynova L. (My Mother Caspian, 2015) and B. Agharzayeva (A Study on the Volume of Pollutants in the Azerbaijani Aquatorium of the Caspian Sea, Baku, 2016), the contemporary problems of water use in agriculture by M. Rzayev (Azerbaijan: Reform of Irrigated Cultivation and Environmental Sustainability, Baku, 2019).

\section{The Methods Used in the Article}

In this study, I have used mainly the cartographic, statistical, comparative and regional analysis methods. The aim of using the cartographic method was to reveal the regional differences of the pollution in Azerbaijan. The comparative analysis method was used to compare the degree of pollution experienced in the regions of the country and to explain the reasons for their differences. The results obtained through the comparative analysis methods are mentioned in the article. It was found that air pollution has not been investigated as widely as soil and water pollution. In that regard, the data on air pollution in the article were obtained from rare scientific articles, the website of the Azerbaijani State Statistics Committee and other sources on the internet. The statistical methods used in the article are based on the data of the Azerbaijani State Statistics Committee. Moreover, the regional analysis method was also applied among the research methods used in the article. This method was used to explain the effects of Azerbaijan's geographical characteristics on the ecological condition. 


\section{Air Pollution}

Starting from the second half of the 20th century, with the rapid development of economic activities and technology, intense anthropogenic air pollution has appeared in Baku and other industrial centres (Sumgayit, Shirvan, Ganja and Mingachevir). Because of the lack of necessary technologies, the extent of air pollution in the aforementioned cities was studied only later. [1]

Azerbaijan's regions that experience air pollution are mostly urban areas, like in many regions of the world. The main sources of air pollutants in the cities are nitrogen dioxide, carbon dioxide, benzopyran, formaldehyde, phenol, carbon-sulphide and hydrogen fluoride. The average annual air pollution has increased 50 percent in the last ten years. [2]

The amount of the emission of $\mathrm{SO} 2, \mathrm{NO} 2$ and hard particles by the Mingachevir New Azerbaijan Thermal Power Plant, the largest of its kind in the country, are 60000, 20000 and 2000 tons respectively. Total amount of the surface level of hard particles is above the norm. Level of SO2 emission in Ali-Bayramli (Shirvan) Power Plant is 4.8 times above the norm. Emission of NO2 is also above the norm in both of the above-mentioned power stations. [3]

The major share of the increasing air pollution in Azerbaijan accounts for the transportation vehicles and industrial facilities.

Table 1. Discarded materials from the transport vehicles in Azerbaijan (thousand tons)

\begin{tabular}{|l|c|c|c|c|c|c|c|}
\hline Years & $\mathbf{1 9 9 5}$ & $\mathbf{2 0 0 0}$ & $\mathbf{2 0 0 5}$ & $\mathbf{2 0 1 0}$ & $\mathbf{2 0 1 4}$ & $\mathbf{2 0 1 7}$ & $\mathbf{2 0 1 8}$ \\
\hline Total & 446,8 & 392,7 & 496,4 & 742,0 & 965,9 & 976,4 & 950,2 \\
\hline $\begin{array}{l}\text { Carbon } \\
\text { Oxides }\end{array}$ & 338,8 & 148,2 & 353,7 & 528,3 & 700,3 & 695.6 & 687,3 \\
\hline $\begin{array}{l}\text { Oxides of } \\
\text { Nitrogen }\end{array}$ & 26,9 & 31,3 & 41,6 & 62,3 & 91,1 & 92,6 & 87,0 \\
\hline Hydrocarbons & 81,1 & 56,4 & 67,6 & 101,7 & 151,8 & 161,3 & 156,4 \\
\hline
\end{tabular}

Source: Ministry of Environment and Natural Resources of Azerbaijan, 2019

The growing number of transportation vehicles in the country, notably cars, has led to the increase of materials thrown into the air. In
2017, 1.342.324 units of transport vehicles was registered in Azerbaijan, out of which 1.147.437 are cars. [4]

Every year, the number of cars and trucks in the country increases by 10 percent and it is expected that the number of vehicles will reach up to three million after ten years. Except the number of vehicles, the use of fuel noncompliant with the standards and the absence of exhaust filters, especially in the Russianmade vehicles, plays a major role in the air pollution. Despite the 62 percent decline in automobile imports in 2017, the number of imported cars is reported to be 63 thousand. 72 percent of cars and trucks in the country accounted for capital Baku in 2019. [5]

More than half of the automobiles (more than 1.3 million units) accounted for the Absheron Peninsula in 2018. This explained by the fact that a large part of the population and economic potential of the country is concentrated in this area. More than 60 percent of the production capacity is concentrated in Baku, which has 3.3 million population, and other towns of Absheron. [6]

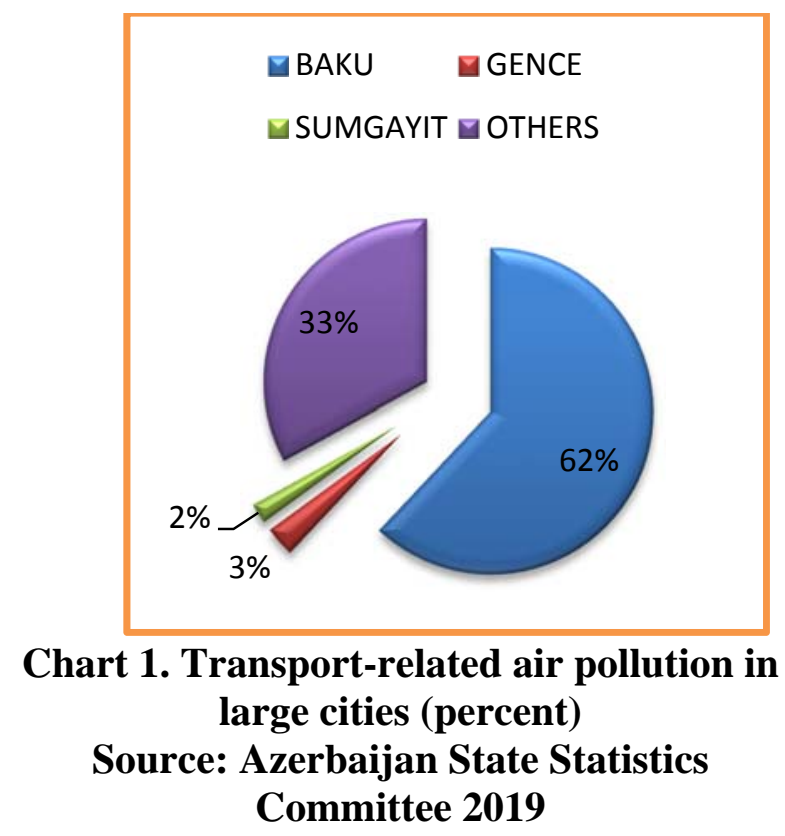

Transport vehicles have a major share among the sources of air pollution in big cities; especially the share of Baku is quite high. Despite the recent measures taken by the government (e.g. the ban on the cars from other areas to enter Baku) to reduce the number of 
cars in the capital, it was not possible to achieve desired results. On the other hand, timely control of the exhaust filter in the vehicles and punishment by the relevant institutions were not effective as well. Most of the cars present in Baku traffic are driven within Baku itself regardless of their registration in other regions. Ganja and Sumgayit cities take the following places in the transport-related air pollution. The rate of transport-related air pollution in big cities is described in the chart.

According to researches, the presence of anthropogenic pollutants (carbon oxides, nitrogenous substances) in the weather during the hot periods of the year stem from transport vehicles. 65-70 percent of the air pollution in large cities of Azerbaijan accounts for the public transport. In recent years, rapid development of industry and transport in large cities also caused an increase of air pollutants. Air pollution in Baku, Ganja and Sumgayit is above the norm. In comparison, excess of pollutants in the air was not observed in Nakhchivan, Sheki, Mingachevir and Lankaran cities. [7]

High air pollution in Baku, Ganja and Sumgayit is explained by the fact that more than 80 percent of the industrial potential of the country is concentrated in these three cities. The share of pollutants emitted by oil and petrochemical, as well as metallurgical and power generation enterprises is higher than others.

Industrial facilities also play an important role in the air pollution. The largest facilities of the metallurgical industry in Azerbaijan are located in Dashkasan, Baku, Ganja and Sumgayit. The "Boruyayma" factory of 1952 in Sumgayit (now "Azerboru" OJSC) and the "Filiz Saflaşdırma" factory of 1954 in Dashkasan are among the first metallurgical plants. In the following years, the number of large metallurgical plants in the country increased after the inauguration of the steel factory in Baku and the aluminium plants in Ganja and Sumgayit. Consequently, these plants contributed to the air pollution in the country. The growing air pollution of Baku is related to the fact that majority of the industrial facilities are located there. The main sources of pollution in Baku are the facilities of such state companies as SOCAR, "Azerigas OJSC", "Metallurgia", "Azneftkimyamash", "Azerindustry Construction Materials". Moreover, the growing disposal of greenhouse gases (effective for global warming) into the air is observed as well.

It should be noted that the need for modernization of oil refineries and installments located close to the densely-populated areas of Baku still remains as a pressing issue. [8]

Table 2. Disposal of greenhouse gases into the atmosphere (equivalent to million ton $\mathrm{CO}_{2}$ )

\begin{tabular}{|l|c|c|c|c|c|c|c|c|}
\hline Years & $\mathbf{2 0 0 5}$ & $\mathbf{2 0 1 0}$ & $\mathbf{2 0 1 1}$ & $\mathbf{2 0 1 2}$ & $\mathbf{2 0 1 3}$ & $\mathbf{2 0 1 4}$ & $\mathbf{2 0 1 7}$ & $\mathbf{2 0 1 8}$ \\
\hline $\begin{array}{c}\text { Carbon } \\
\text { gas (CO }\end{array}$ & 34,8 & 26,4 & 28,8 & 30,2 & 29,5 & 30,2 & 29,8 & $\cdots$ \\
\hline $\begin{array}{c}\text { Nitrogen } \\
\text { oxide } \\
\mathbf{( N O}_{2} \text { ) }\end{array}$ & 0,4 & 3,3 & 3,1 & 3,1 & 3,1 & 3,2 & 3,2 & $\cdots$ \\
\hline $\begin{array}{l}\text { Methane } \\
\text { (CH4) }\end{array}$ & 13,9 & 17,5 & 17,1 & 17,6 & 17,2 & 17,4 & 16,9 & $\cdots$ \\
\hline F-gases & 0,8 & 1,0 & 0,9 & 0,9 & 1,0 & 1,0 & 0,8 & $\cdots$ \\
\hline
\end{tabular}

\section{Source: The State Statistical Committee of the Republic of Azerbaijan, 2019}

There are inter-regional differences in terms of pollutants thrown into the atmosphere from "stationary sources". Baku, Ganja, Sumgayit and Shirvan regions have the largest share of the contaminants. High concentration of industrial activity in these cities is a main reason for this.

\section{Soil Pollution}

The main reasons for soil pollution in Azerbaijan are the oil industry, the excessive use of fertilizers and pesticides and wrong application of the irrigation techniques. More prevalent soil pollution in Azerbaijan is observed in the Absheron Peninsula. This region is considered the cradle of petroleum activities in the world. Eleven million out of 20 million tons of oil produced in the world in 1901 was extracted in this region. Azerbaijan was a petroleum region of the former Soviet Union during the Soviet era until the 1950s and 70 percent of the Soviet oil was produced here during this period. Of course, the impact of the petroleum activities over the environment has been tremendous. Azerbaijan has inherited 
serious environmental problems of the Soviet Union. There are 33.3 thousand hectares of useless land in the Absheron Peninsula (total area of the peninsula is 222 thousand hectares). The oil-contaminated areas are about ten thousand hectares (2800 ha. area is seriously affected). 7.7 thousand hectares out of this amount is located on the lands belonging to the State Oil Company of Azerbaijan (SOCAR). The pollution of soil penetrates three meters in depth. The most contaminated areas of the Absheron Peninsula are Balakhani, Bibiheybet, Bayil, Surakhani, Ramana, Sabunchu and Binagadi districts. This situation is described in the map below. The presence of more oilcontaminated soil in Absheron is mentioned in the various sources.

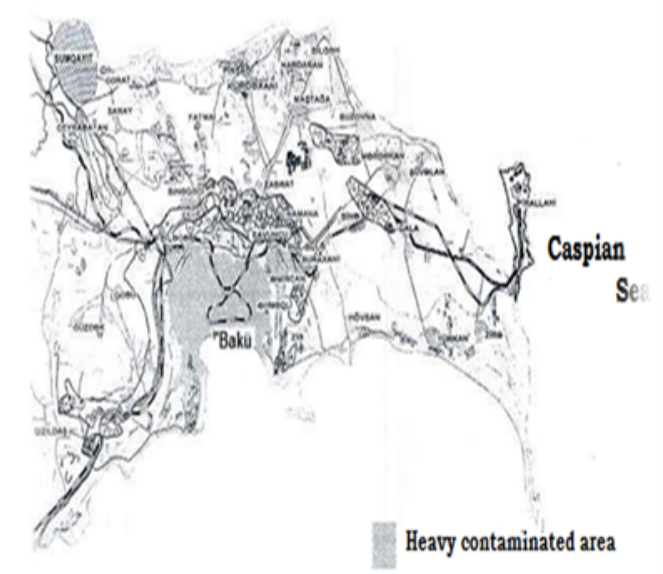

Map 1. The oil-contaminated areas in the Absheron Peninsula (H. Aslanov, S. Seferli, 2010)

During ten years after 2010ç there was not any decrease in the polluted land area in the Absheron Peninsula. Full industrialization and semi-desert natural conditions of the peninsula reduced the chances of restoration of soil by itself to zero. There is no sign of natural ecosystems left in the peninsula. Any important work towards cleaning of the soil from oil-contaminants was not carried out.

The reclamation work in the oil-contaminated areas is more difficult. Oil is an organic substance and it is difficult to wash it out of soil, which requires huge expenses. The oilcontaminated soils are located not only in the
Absheron Peninsula, but also in Salyan, Neftchala, Siyazan and other regions. Despite these areas not being polluted as much as the Absheron Peninsula, however, the pollution negatively affects agricultural activities in the region. Another soil-related problem in Azerbaijan is soil salinization.

Total area of Kur-Araz lowland - the main agricultural region of Azerbaijan - is about 2.5 hectares. There are $0.5-1 \%$ easily soluble salts in 30 percent of the lowland. In the case of excessive irrigation, the level of groundwater increases and the soil begin to become saline in such areas. 130 thousand hectares of area is in this condition and totally unusable. [9]

According to the latest information, 26.8 percent of the irrigated lands in Mil plateau is characterized by unsatisfactory hydrogeological and melioration conditions.

At present, the rising level of salinization, which negatively impacts agricultural productivity in Mil, Mughan and Garabagh plains, as well as in Ganja-Gazakh region, is a pressing problem. [10]

The excessive use of pesticides and fertilizers in agricultural areas during the Soviet era made an additional contribution to the pollution of Azerbaijan's soils. Utilization of fertilizers at least 5-6 times more than the norms per hectare of land has led to pollution and its effects has continued for many years.

One of the environmental problems of Azerbaijan is erosion. The seriousness of its size is noteworthy. The destruction of forests in the last 30 years has caused the acceleration of erosion and expansion of the area it covered. 42 percent of Azerbaijan's territories have undergone various degrees of erosion. The state of erosion by region is as follows:

\section{Table 3. The eroded areas in Azerbaijan}

\begin{tabular}{|c|c|c|c|c|}
\hline No & Regions & $\begin{array}{c}\text { Total area } \\
\text { (thousand } \\
\text { hectares) }\end{array}$ & $\begin{array}{c}\text { Eroded } \\
\text { areas } \\
\text { (thousand } \\
\text { hectares) }\end{array}$ & Percent \\
\hline $\mathbf{1}$ & Absheron & 323.3 & 87 & 26.9 \\
\hline $\mathbf{2}$ & $\begin{array}{c}\text { Guba- } \\
\text { Khachmaz }\end{array}$ & 804.85 & 510.4 & 63.4 \\
\hline $\mathbf{3}$ & Shirvan & 879.38 & 305 & 34.7 \\
\hline $\mathbf{4}$ & Sheki-Zakatala & 1041.4 & 497 & 47.7 \\
\hline $\mathbf{5}$ & Ganja-Gazakh & 1246.8 & 788 & 63 \\
\hline $\mathbf{6}$ & Mil- Karabakh & 284.9 & 29.5 & 10.3 \\
\hline $\mathbf{7}$ & $\begin{array}{c}\text { Mughan- } \\
\text { Salyan }\end{array}$ & 171.6 & 63.8 & 37 \\
\hline
\end{tabular}




\begin{tabular}{|c|c|c|c|c|}
\hline $\mathbf{8}$ & Lankaran & 636.3 & 204.2 & 2.32 \\
\hline $\mathbf{9}$ & Arazboyu & 316.6 & 206.5 & 65 \\
\hline $\mathbf{1 0}$ & $\begin{array}{c}\text { Upper } \\
\text { Karabakh }\end{array}$ & 487.9 & 279.8 & 56 \\
\hline $\mathbf{1 1}$ & $\begin{array}{c}\text { Kubadly- } \\
\text { Kalbacar }\end{array}$ & 370.5 & 312.2 & 84.2 \\
\hline $\mathbf{1 2}$ & Nakhchivan & 536.3 & 401.6 & 75 \\
\hline
\end{tabular}

Source: A. Babayev, Supervision and Control of Soil Ecology Quality, Baku, "Law" Publishing House, 2011. p. 40

As is shown in the table, the eroded soils are more in Ganja-Gazakh, Shirvan, and ShekiZagatala regions.

Researches and comparison with previous years indicate that during the last ten years, eroded areas in Azerbaijan have not decreased, and in some regions (Absheron Peninsula, Shirvan) even increased. [11]

In Mughan-Slayan region, 18.5 percent of lands were subject to strong erosion and 14.84 percent - to very strong erosion. In the south of Mughan region, these indicators are 15.48 percent and 24.01 percent respectively. [12]

The erosion and desertification keeps increasing by virtue of climate change and direct human activities. A part of Azerbaijan's polluted and degraded lands are located in the beach areas. The beach sands are often carried to other areas as construction materials. Some beach areas were closed with fences to the public by businessmen.

\section{Water Pollution}

The water pollution in Azerbaijan can be classified into two groups. The first group includes the pollution of the Caspian Sea, while the second group includes that of Azerbaijan's rivers and lakes. The main sources of pollution of the Caspian Sea are unfiltered industrial products, agricultural wastes, sea and river navigation, land and searun oil wells, and the pollutants caused by the deepening of the seabed and brought by air and water.

Active development of oil fields in the Caspian Sea started as of the 1950s. All of the stateowned sectors have been polluted at different levels. According to the researches, threequarters of the Caspian's surface water was contaminated. The pollution of the sea during the Soviet era was more than the norms. The oil concentrates norm is ten times higher in the Baku bay, 2-7 times higher in the other regions.

On average, 12 billion cubic meters untreated wastewater, 1500 tons of oil waste, 1400 tons of phenol and 3400 tons of active synthetic substances are annually discharged to the Caspian Sea by the littoral countries. As a result, the radioactivity indicator in living organisms has increased from 10 times to 30 times. Solidity of some ingredients are observed 10-40 times above the norm. [13]

Annually 839.4 tons of waste are discharged to the Caspian Sea, of which 605,1 thousand tons are discharged through the Volga River, 49.7 thousand tons through Kura River, 21.5 thousand tons through Terek River, 9.1 thousand tons through Ural River, 2.6 thousand tons through Samur River, 417.1 tons through Sefidrud River and 642 tons through relatively smaller rivers. [14]

The changes in the level of the Caspian Sea present another serious problem. Thus, when the level of the Sea goes down, the reconstruction of the hydro-technical structures and sea ports is needed. As a result of the water withdrawal, the fauna area of the Caspian Sea is reduced, which impeded the movement of fish to the rivers for spawning. When the sea level rises, the ecological situation is worsening in the coastal areas, marshes occur, and infrastructures and houses on the coast remain under water.

2.5-meter rise in the water level during the year resulted in flooding in 1-2 km coastal line. A number of residential settlements and farms located along the coastal line in the southern region (Lankaran-Astara) were impacted by this disaster, and a serious material damage incurred to the population and the state. [15]

Although 20 contracts on extraction of oil and gas resources of the Caspian Sea have been signed, ecological standards on the Caspian Sea have not been prepared yet. The protection of fish also remains as an unaddressed issue. [16]

One of the serious environmental problems of Azerbaijan is river pollution. The largest rivers of the country - Kura and Araz - are contaminated while passing through Georgia 
and Armenia to Azerbaijan. Kura River is polluted with industry, agricultural and household waste in Georgia.

Three million cubic meters of sewage and wastewater from industrial plants located in Borjomi, Akhalbaba, Khasuri and Gori cities and other residential settlements of Georgia located along Kura River daily. The river is even highly polluted in Tbilisi, which it cuts across in a 40-km line. [17]

Another water-related problem in Azerbaijan is that some irrigation water is wasted due to the outdated infrastructure. The surface of only 4.1 percent of water channels is covered. As more than 95 percent of the channels do not have any surface cover, 2.5-3.5 billion cubic meters of water is wasted annually.[18]

One of the crucial issues in undertaking a plan of measures for revitalization of rivers is ensuring the ecological flow of the river. Unfortunately, there is no normative document on determining the ecological flow of rivers in Azerbaijan. [19]

The lack of operational management and necessary technical means in water distribution leads to the non-rational use of water, its discharge into the collector-drainage network and non-compliance with the water demand schedule, which result in the worsening of the melioration condition of lands. [20]

The most serious cases of extreme pollution of Araz River are happening in the Armenian territories. Various metal waste are thrown from the metallurgy plants in the south of Armenia into the Okchuchay River, which joins the waters of Araz River.

Hundred thousand tons of acidic waters, heavy metal salts and other hazardous waste from mining and metal refining plants located in Meghri, Kajaran, Kafan and Dastakert districts of Armenia extremely pollute Okhchuchay River. In various times the amount of copper in the water was 25-50 times, while the amount of phenols was 6-15 times higher than the standard. Such polluting elements as aluminum, zinc, manganese and titanium are always found in the waters of Okhchuchay River. Metsamor Nuclear Power Plant of Armenia is directly connected to Araz River. 12-16 thousand cubic meters of pollutants are discharged into Araz d River daily. There a very high possibility that this will cause disasters for Araz River and its tributaries in the future.

Large Sarsang and Khachinchay water reservoirs of Azerbaijan are under the occupation of the Armenian army since 1993. As no technical service was provided to these water reservoirs and their equipment since the time of occupation, they are currently in emergency situation. Due to the geographical relief structure of the area, these water reservoirs are a serious source of threat to the security of approximately 700 thousand residents of Azerbaijan who live under the level of those reservoirs. [21]

President of Azerbaijan Ilham Aliyev also raised the seriousness of this issue on February 13, 2016. President Aliyev discussed the excessive pollution of Araz River in the Armenian territories and Armenia has not responded to the calls of Azerbaijan on the termination of pollution, [21]

Araz River is also polluted in the territory of the Islamic Republic of Iran. There is very little information on this issue. However, it is a known fact that annually 71 thousand tons of fertilizers and 572 thousand tons of pesticides are used in the Iranian basin of Araz River, and some part of them are discharged to Araz River by the waters flowing to the river from irrigated lands. [22]

Contamination of the internal waters of the Absheron Peninsula, where more industrial activities are concentrated, is out of question since the river network is not well-developed. The river pollution is observed in all the regions outside of the Absheron Peninsula. The sources of river pollution in other regions of Azerbaijan are wastes thrown from the industrial plants and houses, as well as pollutants emanating from the agricultural activities. The overflow of the Kura River during certain periods in Azerbaijan damages sown areas and houses close to the river. Cleaning of the river delta and construction of protective dams are ongoing during past years. Serious differences in water consumption are observed countrywide. As indicated in the map below, the highest level of water consumption 
is in Baku, Ganja and Sumgayit, where the water infrastructure is well-established. There is a serious control over water quality in big cities, while the same cannot be said for other regions. Water shortage is prevalent mostly in the areas where river network is underdeveloped.

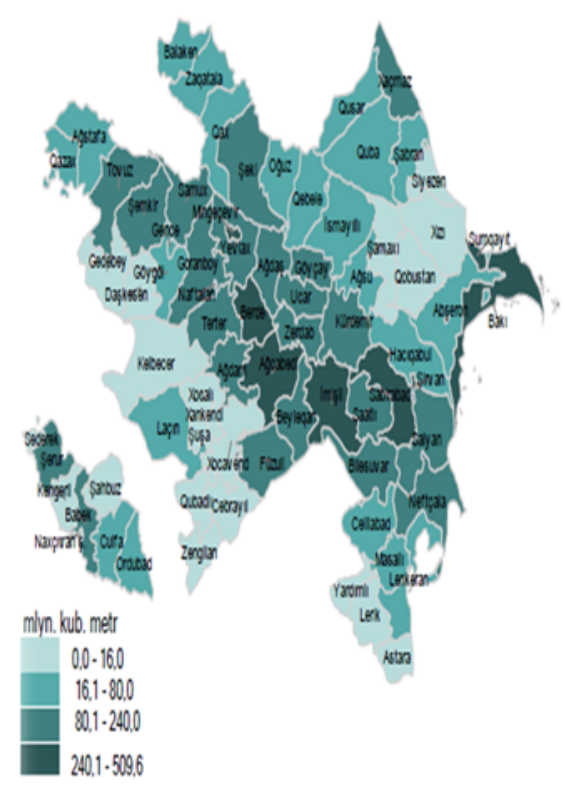

\section{Map 2. Water consumption in Azerbaijan's regions and cities}

\section{Other pollution types}

Other types of pollution in Azerbaijan are radiation, noise and visual pollution. The main source of radioactive contamination until 2012 had been Gabala Radar Station. The decision on the construction of Gabala Radar Station were made by the Central Committee of the Communist Party of the Soviet Union in 1975. According to the decision, mountainous areas of 210 hectares in Zaragan village of Gabala district, located $320 \mathrm{~km}$ northwest of Baku, was allocated to the Soviet Union's Ministry of Defense. A year after the completion of construction of the radar station in 1984, it launched its operations on February 20, 1985. In terms of technical specifications, it was considered one of the crucial radar stations of that period. [23]

In the Soviet period, the harms of this station to the environment and human health had not been a topic of discussion. After the collapse of the Soviet Union, the harms of Gabala Radar Station to the environment and human health made headlines in the press. As a result of the station's activities, a number of diseases (in particular cancer and respiratory diseases) and a serious decline in the rate of fertility among women have been identified. At the end of 2012, the station was closed.

Noise pollution is observed primarily in big cities. Researchers identified that noise pollution in the air spaces and in the big construction sites cause some discomfort in Baku, Sumgayit and Ganja cities.

Visual pollution is observed in more dump space environment and in the areas, where the infrastructure work is carried out slowly.

\section{Discussion}

Analysis of the literature on environmental problems of Azerbaijan shows that the main ecological problems of the country, especially air, soil and water pollution problems have been thoroughly studied, and recommendations for solving certain problems have been made. Nevertheless, a number of environmental issues that can play an important role in the solution of ecological problems have not been adequately addressed in the previous studies. They are the following:

- How should the cooperation between the public sector, private sector and non-governmental organizations be established with regard to the solution of environmental problems?

- How should the role of nongovernmental organizations be increased?

- How should the mechanism for application of the ecological standards be established?

- In what ways should the environmental awareness be increased, and environmental education be carried out in a systematic way?

- How should the responsibility for the environmental problems be shared between the polluters and the consumers? 
- Best practices of which countries should be given preference in order to solve the environmental problems?

- How should the Environmental Impact Assessment reports be drafted and how should their functioning mechanisms be established?

- Environmental problems connected with the destruction of ecosystems in the Azerbaijani territories occupied by Armenia continue to aggravate, and effective efforts should be made for intervention of the relevant international organizations to solve these problems.

Solutions to the above mentioned issues can play an important role in the solution of the environmental problems of Azerbaijan, and therefore, these issues should be included in the state conception on ecology.

\section{Conclusion and recommendations}

The industrial pollution in Baku emerged since 1870 s with the large-scale expansion of oil exploration operations in the Absheron Peninsula. With the development of other industrial sectors, transport and agriculture during the Soviet era, the environmental pollution has reached a larger scale in some places. The lack of public information on environmental pollution during the Soviet era, passiveness of non-governmental organizations, absence of environmental awareness and lack of sufficient attention towards the environment by the government made it difficult to solve these problems.

After Azerbaijan re-gained its independence in 1991, the country has had a right to carry out an independent environmental policy. As of the early 1990s, the occupation of the Azerbaijan's territories by Armenia through the support of great powers, and the subsequent presence of approximately one million Azerbaijani refugees have made it difficult for the country to allocate enough resources to its environmental programs.

After achieving a certain political and economic stability in the country, Azerbaijan has implemented a number of environmental programs within the country and has expanded its cooperation with international organizations on the environmental issues.

In order to bring sustainable solutions to environmental problems in Azerbaijan, it is necessary to put into effect environmental standards, and take into consideration the economic, legal and technological standards, as well as administrative aspects as a whole.

Implementation of the following activities would be useful to solve the environmental problems of Azerbaijan:

- The resources allocated for environmental issues should be increased and the realization of the environmental programs should be implemented under the strict and transparent control of the government;

- Collaboration with international environmental organizations should be extended and the experience of developed countries in solving environmental problems should be studied;

- The oil-contaminated areas should be re-defined, and the society should be well-informed of the relevant areas;

- The oil-contaminated soils of the Absheron Peninsula must be brought into a convenient condition for agriculture;

- Control over foreign companies involved in oil exploration activities in the Caspian Sea should be increased and the implementation of sanctions and fines should be activated;

- The majority of industrial facilities should be donated with treatment (filtration) devices and the industrial facilities without the treatment devices should not be allowed to operate;

- Environmental Impact Assessment projects should be compulsory for the new facilities to be opened;

- Structural changes should be made in the passive environmental agencies;

- The forest areas should be re-defined again and the necessary measures should be taken to restore the destroyed forest areas; 
- The ecological status of area and surroundings lands, where previously the Gabala Radar Station located, should be studied with modern methods;

- To improve the quality of personnel in the field of ecology, a separate university of ecology should be established and it should be provided with modern laboratories and highly qualified staff;

- The laboratories should be established within the customs office of the country as soon as possible for rapid control of the quality of food and related products;

- The environmental legislation of the country should be improved and upgraded to the level of world standards.

- The country's drainage and collector structure should be reassessed and the infrastructures made during the Sovietera must be renewed;

- Special programs should be prepared for television and radio to promote environmental awareness;

- State control in food production and outlets should be strengthened.

- Atlas of Azerbaijan on natural and historical attractiveness that has been destroyed must be prepared and presented to the world community.

- Effective efforts should be made for interference of the relevant international organizations to solve the aggravating environmental problems in the Azerbaijani territories occupied by Armenia.

- For collecting different wastes separately, application of underground vacuum system, broadly used in the EU countries today, can be very useful.

\section{REFERENCES}

[1] Mammadova S. I. The current situation on the study of the anthropogenic air pollution of

City and on researches conducted in this area, Baku University News, Natural Sciences
Series. 2009. No. 3, pp. 215-219.

[2] Mammadov G.S., Khalilov M. Y., Mammadova S.Z. Ecology Atlas, Baku, 2009.

[3] Mammadov G., Khalilov M. Ecology and Protection of the Environment, Bak1 "Elm" Press, 2005.

[4] The State Statistical Committee of the Republic of Azerbaijan, Baku, http://www.stat.gov.az/source/transport/. 2019.

[5] "How many cars are there in Azerbaijan? Statistics".

https://yenisabah.az/22112/azerbaycandane-qeder-avtomobil-var. 12.09.2019.

[6] Bayramly K. N., Vagabov M. M., Eldarov E. M. "Formation of motor transport cluster in Azerbaijan: tendencies and problems", Science Review: Theory and Practice, Volume 9, Issue 4, 2019, Continuous issue 60.

[7] Aliyev R.H. Alternative Energy and Ecology, "Teknur" publishing house. Baku, 2015.

[8] Babaev A.M. "Strategic approaches to the formation and management of the ecological and economic system in the oil sector in terms of global challenges", Geostrategy (Geostrategiya), 2019, No. 1(49), pp. 46-49.

[9] Aliyev H. A. Alarm Drum, Ministry of Ecology and Natural Resources, Baku, 2002, p. 14.

[10] Mammadova E.A. Melioration Hydrogeology, "Leman" Publishing House, Baku, 2016.

[11] The problem of soil erosion in Azerbaijan, https://www.bizimyol.info/az/news/518 97.html, 15.03.2018.

[12] Aliyev B.G., Aliyev I.N. Erosion Problems in Azerbaijan and the Ways of Their Solution, Baku, "Nurlan" Publishing House, 2000.

[13] Huseynova L. M. My Mother Caspian, Baku, "East-West" Publishing House, 2015.

[14] Ahgarzayeva B.A. "A Study on the Volume of Pollutants in the Azerbaijani Aquatorium of the Caspian Sea", Water Problems: Science and Technologies, No:4/2016.

[15] A great famine is approaching, https://sputnik.az/life/20191001/421884851/ 
azerbaycanin-su-ehtiyati-azalir-sebeb.html, 01.10 .2019

[16] Shovgi Goeychayli and Telman Ismayilov. Economic and Environmental Bases of Nature Use. Baku, MBM Publishing House, 2009, p. 173.

[17] Qaşqay R.M. Ecological condition of transboundary rivers in Azerbaijan, Institute of Geography of the Academy of Sciences Azerbaijan, http://old.igaz.az/index.php/az/anas-hif/78-sas/513-az-rbaycanda-transs-rh-daylar-n-ekoloji-v-ziyy-ti-v-onlar-n-sosialiqtisadi-saslar, 04.03.2020.

[18] Babayev A.H. Monitoring of the Soil Quality and Environmental Control. Baku, "Qanun" Press, 2011.

[19] Imanov F.A., Ismayilov R.A., Nuriyev A.A. Revitalization and Ecological Flow of Rivers. Baku, "Esoprint" Publishing House, 2019.

[20] Rzayev M.A. Azerbaijan: Reform of Irrigated Cultivation and Environmental Sustainability. Baku, "Science and Education" Press, 2019, p. 372.

[21] Rzayev O.N. "Water crisis and environmental threat", Ikki sahil newspaper, 12.10.2019. No. 188, p. 10.

[22] Imanov F.Ө., Alakbarov A.B. Contemporary Modifications and Integrated Management of the Water Resources of Azerbaijan. Baku, "Mütercim" Press, 2017, p. 352.

[23] Ismayil E. Gabala Radar Station problem in Azerbaijan-Russia relations, http://www.bilgesam.org/incele/170/azerbaycan-rusya-iliskilerinde-gebele-radaristasyonu-sorunu/\#.Vu2U09KLRdg, 02.01.2012. 